九州大学学術情報リポジトリ

Kyushu University Institutional Repository

The Optimization of The Relationship between Octane Number of Gasoline-Ethanol Blend Fuels in Various Settings of The Engine Control Module

CahyoSWibowo

Department of Mechanical Engineering, Faculty of Engineering, Universitas Indonesia

Adian, Fransiskus

Department of Mechanical Engineering, Faculty of Engineering, Universitas Indonesia

YuliantoSNugroho

Department of Mechanical Engineering, Faculty of Engineering, Universitas Indonesia

Sugiarto, Bambang

Department of Mechanical Engineering, Faculty of Engineering, Universitas Indonesia

https://doi.org/10.5109/4150510

出版情報：Evergreen. 7 (4)，pp.587-592，2020-12. 九州大学グリーンテクノロジー研究教育センター バージョン：

権利関係 : 


\title{
The Optimization of The Relationship between Octane Number of Gasoline-Ethanol Blend Fuels in Various Settings of The Engine Control Module
}

\author{
CahyoSWibowo $^{1,2^{*}}$, Fransiskus Adian $^{1 *}$, YuliantoSNugroho ${ }^{1}$, Bambang Sugiarto ${ }^{1 *}$ \\ ${ }_{1}^{1}$ Department of Mechanical Engineering, Faculty of Engineering, Universitas Indonesia, 16424, Indonesia \\ ${ }^{2}$ Research and Development Centre For Oil and Gas Technology “LEMIGAS” Jakarta, 12230, Indonesia
}

*Corresponding Author’s: fransiskus.adian@gmail.com, bangsugi@yahoo.com, cahyoswibowo@gmail.com,

(Received November 4, 2020; Revised December 9, 2020; accepted December 16, 2020).

\begin{abstract}
This study present the performance optimization of a spark ignition (SI) engine using gasoline fuels with variations of research octane number $(88,92$, and 98 ) with 40 volume \% of bioethanol. The optimization is done by setting the spark ignition time ( $2^{\circ} \mathrm{CA}$ advanced) and fuel injection duration (10\% reduction) of the engine control module. The engine was tested using an engine dynamometer test to obtain the performance data at the shaft speed of 1000, 1500, 2000, and 2500 RPM and wide-open throttle conditions. From the results of this study, we conclude that optimizing the engine control strategy can lead to the improvement of engine power, torque, and specific fuel consumption which are more significant with the usage of fuels with higher octane number.
\end{abstract}

Keywords: bioethanol; engine control module; ignition timing; injection duration, octane number

\section{Introduction and background}

Currently, there are energy issues and problems being faced by Indonesia, including dependence on imports of fuel, inefficient utilization of energy, and the low utilization of new and renewable energy. Furthermore, the usage of fossil fuels has some contribution to environmental damage ${ }^{1)}$. Fossil fuel production and distribution, and the combustion process of fossil fuel in the engine emit greenhouse gases into the atmospheres ${ }^{2}$. Renewable energy is a potential option for energy security and energy sustainability). In correspond to deal with these problems, the Government of Indonesia implements some policies to utilize bioethanol as the blending component to gasoline on the transportation sector. Fossil fuel, in this case gasoline, still use as the main component in ethanol-gasoline blend is based on its quantity that available for several hundred years ${ }^{4)}$

The mixture of ethanol-gasoline can be utilized as fuel for spark ignition (SI) engines even there is no additives addition in it ${ }^{6}$. Mixture of ethanol-gasoline has a lower coefficient of variation (COV) and has reduced exhaust emissions, such as $\mathrm{CO}$ and $\mathrm{HC}$ concentration of the ethanol is increases ${ }^{5)}$. Five volume $\%$ of ethanol added to gasoline (E5) will increase its octane number and give benefits to increase the engine power, torque and decrease the value of specific fuel consumption $(\mathrm{SFC})^{7}$. Engine performance increases with the increase in the composition of ethanol in gasoline ${ }^{8}$. However, the utilization of ethanol-gasoline blends especially in a high percentage of ethanol needs further study to optimize its performance in relation to its heating value which is lower than gasoline ${ }^{9)}$ and thus it will lower the ethanol-gasoline blend heating value ${ }^{10)}$. The utilization of fuel with low heating value will have an impact on reducing engine performance and increasing the SFC. Al-Baghdadi stated that ethanol addition by $30 \%$ in gasoline could increase the SFC by $4.3 \%{ }^{11)}$. This is influenced by the fuel/air ratio of the ethanol-gasoline blend which is higher than gasoline so that the fuel mass flow rate or the fuel consumption becomes higher in order to achieve the same power ${ }^{9)}$.

On the other hand, ethanol addition to gasoline will increase the octane number of the mixture. The results of the study by B. Sugiarto et al. (2018) stated that by adding 5 volume $\%$ to 20 volume $\%$ of ethanol to gasoline base fuel with a lower initial octane number gasoline base fuel will increase its octane number more significant than to gasoline base fuel which already has high octane number ${ }^{12)}$. The octane number of gasoline, especially the research octane number (RON), is an important parameter to indicate its anti-knock characteristics ${ }^{13)}$. In particular engine compression ratio, the use of high octane fuel has a better combustion process which will result in higher engine torque ${ }^{14)}$. Because of its higher octane number, the ethanol-gasoline blend is suitable to be used in an engine with a higher compression ratio ${ }^{9}$. Engines with a higher 
compression ratio can increase the efficiency of engines, but they require a higher octane number fuel to reduce the knock tendency ${ }^{10,15)}$.

Engine performance is affected by several factors, including engine operating conditions, engine design, and the properties of fuel/air mixture ${ }^{16)}$. Among those factors, spark timing is the main parameter to be controlled to optimize engine performance (fuel economy, torque ${ }^{18)}$.

To run successfully on gasoline-ethanol blends, it needs to advance the engine timing of the standard SI gasoline engine ${ }^{18)}$. Varying the ignition timing and regulating the fuel injection to its stoichiometric mixture are included as an engine control strategy to obtain the optimum engine performance ${ }^{19)}$. Ignition timing should be set at or near mean the best torque (MBT) since the engine torque output is maximum at $\mathrm{MBT}^{19)}$

There are several studies related to the setting of ignition timing. Kar and Cheng (2009) stated that with the increase in ethanol percentage, the knock resistance of the mixed fuel will increase ${ }^{20)}$. Thus, knock is no longer a limitation in setting ignition timing. Knock has been a limitation when using gasoline fuel. With the knock limit, the ignition timing can be advanced closer to the MBT value for the use of a mixture of ethanol and gasoline fuels to avoid knocking. Ritchie Daniel et al. (2012) stated that ethanol requires the most advanced spark timing compared to gasoline ${ }^{21)}$. This is caused by spark timing gasoline which is limited by knocking. Different opinions expressed by Pedro Mello et al. (2014) which stated that the addition of ethanol mixed with gasoline need to delay the ignition timing to avoid knocking because of its higher speed flame propagation compared to gasoline. By reversing ignition timing, it will reduce the tendency for detonation to occur, but at the same time reduce power output and fuel efficiency ${ }^{16)}$. To get the highest efficiency with the use of a high percentage of ethanol content in the mixture of ethanol-gasoline fuel, retarding the spark ignition timing has to be done. The reason why we need to delay the start of combustion is that the duration of combustion initiation and main combustion duration is reduced as the ethanol content is increased ${ }^{22}$. The ethanol added to gasoline improves the combustion process, reduces the combustion duration, reduces the ignition delay, and speeds up the flame front propagation ${ }^{11)}$. The flame propagation rate of ethanol and the ethanol-gasoline blend is higher than non-oxygenated fuels in all engine compression ratios ${ }^{16)}$. Fuel with higher burning speed needs smaller advancements of ignition timing. Higher ignition advancement is required for low flame speed fuels to maximize the engine torque ${ }^{16)}$. On the other hand, retarding the ignition timing will reduce the engine power and reduce fuel efficiency, although the tendency to detonate is also reduced ${ }^{23)}$. When using a higher octane number of blend fuel, some engines may be able to adjust their ignition timing (advanced) and improve their fuel consumption at knock-limited operating conditions ${ }^{25)}$. The onset of knock ultimately limits the maximum allowable spark advance and prevents the use of the theoretical optimum (MBT) timing ${ }^{21)}$. A higher octane rating of fuel allows more advanced spark timing and combustion phasing under knock limited conditions because its knock resistance is improved ${ }^{26)}$. Currently, in some countries market, fuel is gasoline blends Ethanol $10 \%-20 \%$ percentage volume for vehicles without modification used for the conventional engine ${ }^{28)}$ and familiar E85 for use in flex-fuel vehicles ${ }^{29,30)}$, in this study focus with blend $40 \%$ volume ethanol.

With so many fuel choices marketed in Indonesia, consumers have the potential to choose fuels with octane values that are not suitable with the specifications of the engine used, so that it can have an impact on reducing engine performance and increased fuel consumption. This research purpose is to obtain data on engine performance and specific optimum SFC for an ethanol-gasoline blend with a different octane number of gasoline base fuels with blend ethanol $40 \%$ volume in various conditions of ECM settings, including ignition timing and injection duration.

\section{Method and experimental setup}

In this study, we prepare three types of Indonesia commercial gasoline as base fuels, consist of gasoline RON 88, 92, and 98, of which main characteristics are described in Table 1 below and Fuel Grade Ethanol (concentration- 99,5\%). Those base fuels are blended with fuel-grade ethanol by the composition of 40 volume \% and coded by 88 E40 (blend of gasoline RON 88 with 40 volume \% of ethanol), 92 E40 (blend of gasoline RON 92 with 40 volume \% of ethanol), and 98 E40 (blend gasoline RON 98 with 40 volume \% of ethanol). Determination of Research Octane Number (RON) used CFR engine - F1 accordance ASTM D $2699^{12,26)}$ and value density accordance ASTM D $4052^{27)}$

Table 1. Characteristics of ethanol-gasoline blend

\begin{tabular}{|l|c|c|c|}
\hline \multicolumn{1}{|c|}{ Parameter } & 88E40 & $92 \mathrm{E} 40$ & $98 \mathrm{E} 40$ \\
\hline Ethanol content, vol.\% & 40 & 40 & 40 \\
\hline RON & 103 & 105 & 108 \\
\hline Density at $15^{\circ} \mathrm{C}, \mathrm{kg} / \mathrm{m}^{3}$ & 753.2 & 760.9 & 765.3 \\
\hline
\end{tabular}




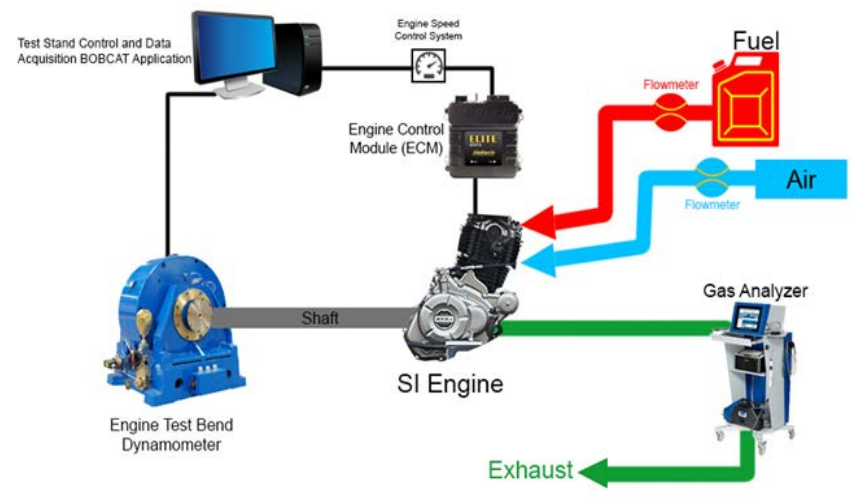

Fig. 1 AVL Engine Dynamometer Test bench Scheme

We prepared the engine performance tests at Research and Development Centre for Oil \& Gas Technology "LEMIGAS" laboratory, using a 150 cc, single-cylinder, four-stroke motorcycle engine as the test engine that be connected to AVL engine dynamometer. All of the performance tests were conducted at wide-open throttle (WOT) because it was stated in some literature that knocking in this condition was most problematic 20). The shaft speeds were varied by 1000 RPM, 1500 RPM, 2000 RPM, and 2500 RPM. We measured the engine power and torque output, fuel consumption, and then calculate the specific fuel consumption (SFC) for each variation of shaft speed.

To improve the engine performance, we set the ignition timing of the spark plug $2^{\circ} \mathrm{CA}$ more advanced (notated with IT +2 ) and a reduction of fuel injection duration by $10 \%$, (notated with FI $-10 \%$ ) of the ECM (Haltech Elite 550) compared to its standard conditions.

\section{Results and Discussion}

A. Engine Power and Torque

It has been seen from Figure 2 that by setting the ignition timing of $2{ }^{\circ} \mathrm{CA}$ and reducing fuel injection duration by $10 \%$ can increase the engine power compared to standard ECM conditions with the use of 88 $\mathrm{E} 40,92 \mathrm{E} 40$, and $98 \mathrm{E} 40$ fuels. The increase in engine power is greater in the use of fuel with a higher octane value, which is 6\% (88 E40), 9\% (92 E40), and 11\% (98 E40) at 2500 RPM shaft speed.

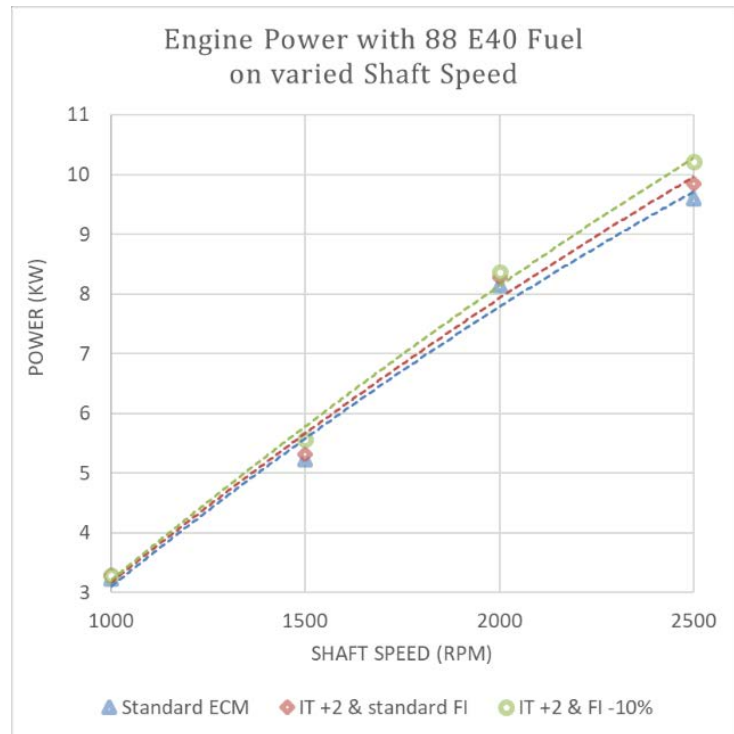

(a)

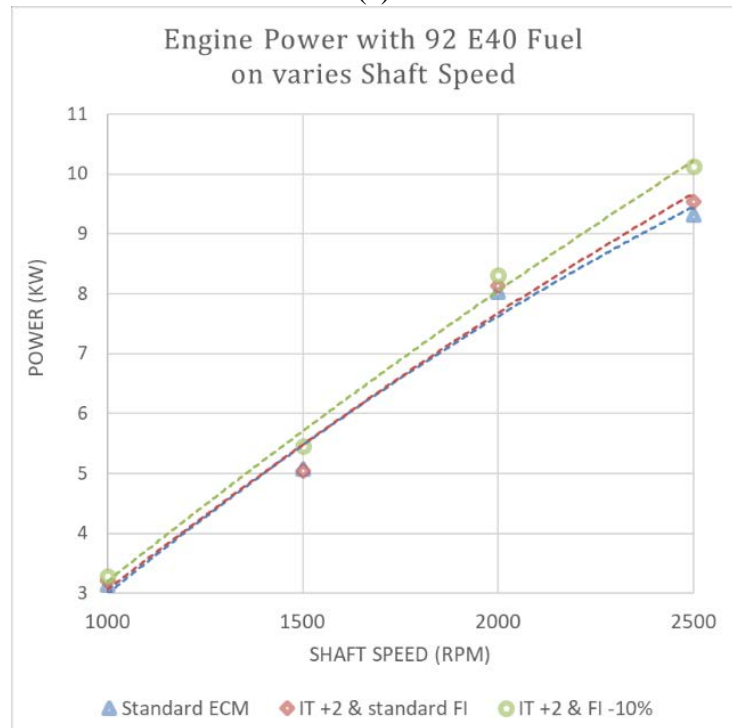

(b)

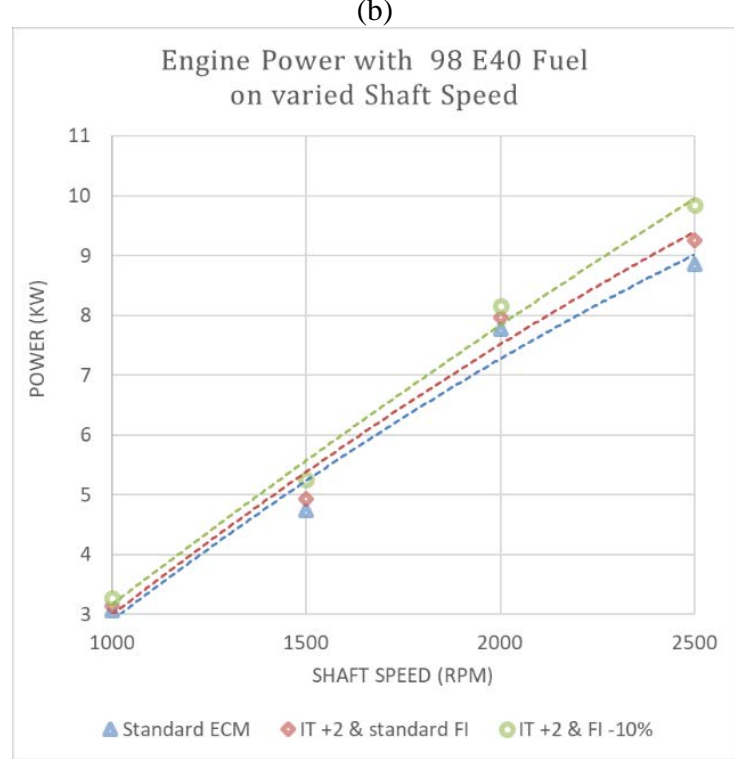

(c)

Fig. 2: Engine Power with Different RON Fuel on Varied Shaft Speed (a) 88 E40, (b) 92 E40 and (c) 98 E0 - E40 


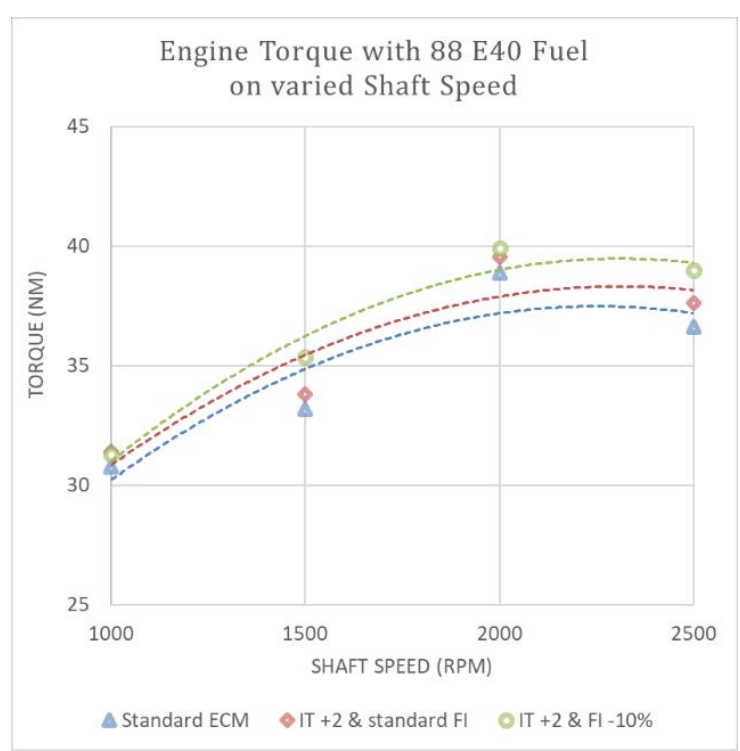

(a)

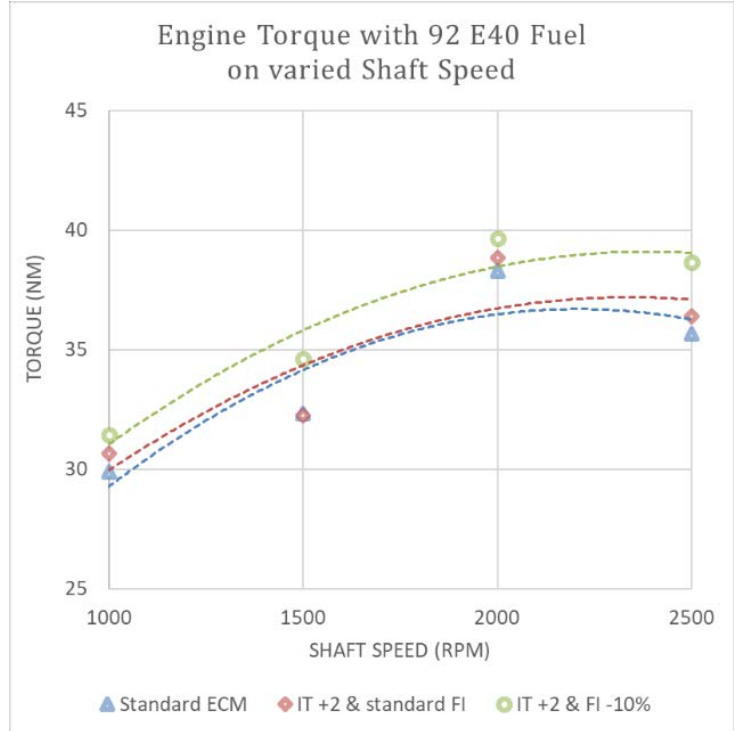

(b)

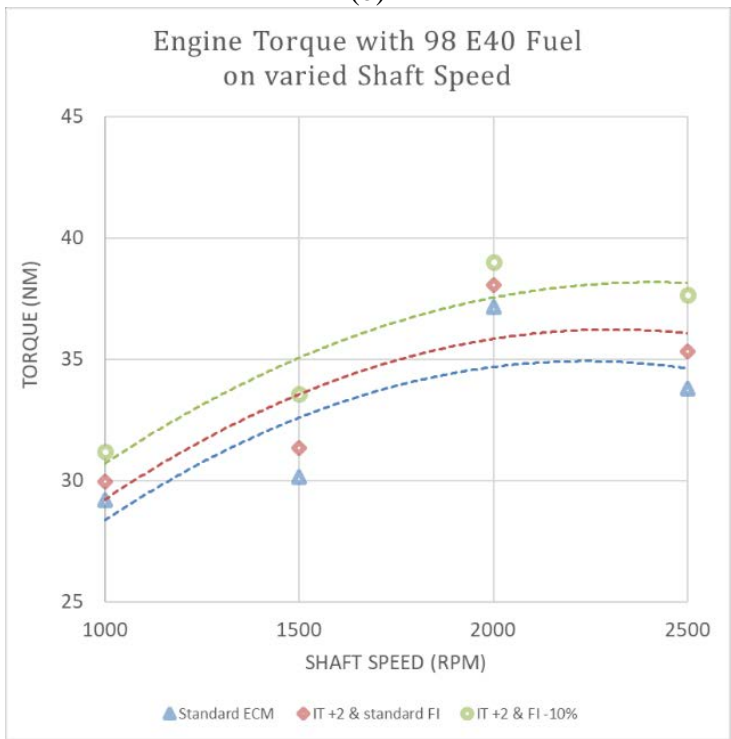

(c)

Fig. 3: Engine Torque with Different RON Fuel on Varied Shaft Speed (a) 88 E40, (b) 92 E40 and (c) 98 E0 - E40

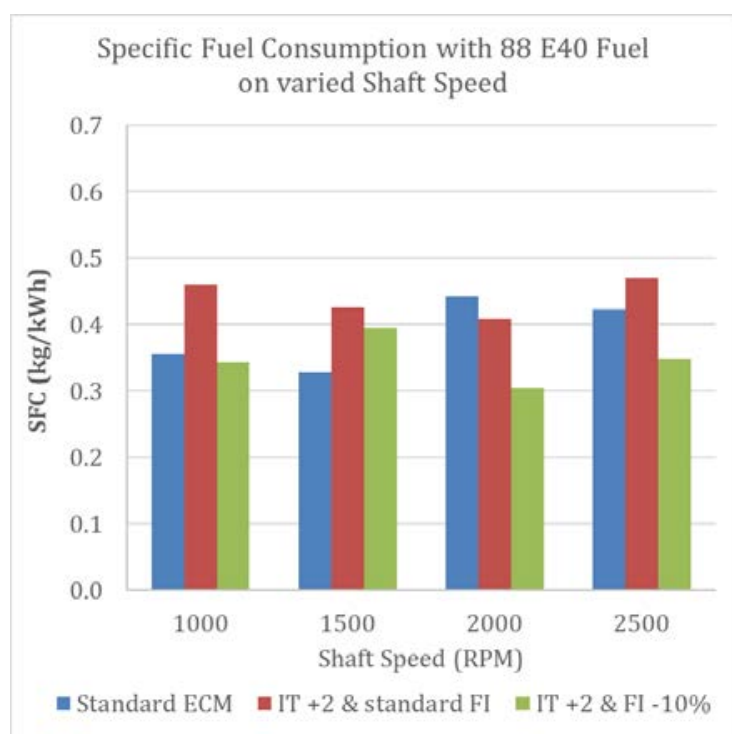

(a)

Specific Fuel Consumption with 92 E40 Fuel on varied Shaft Speed

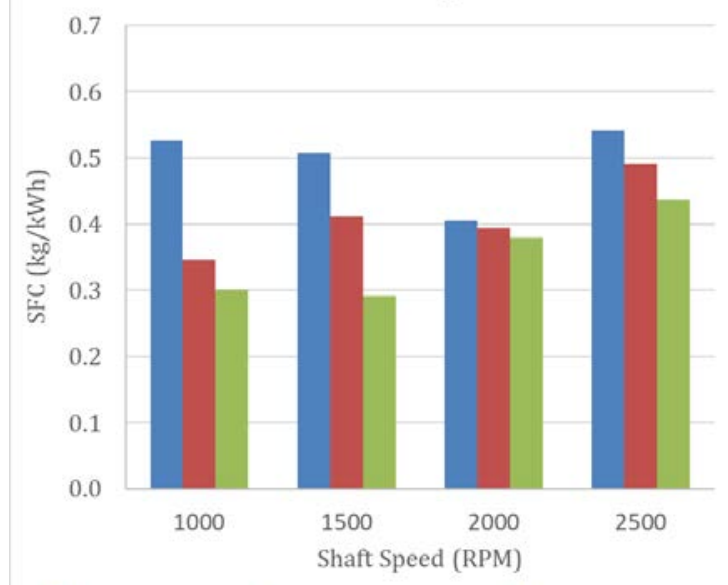

= Standard $\mathrm{ECM}$ = IT +2 \& standard FI $=\mathrm{IT}+2$ \& FI $-10 \%$

(b)

Specific Fuel Consumption with 98 E40 Fuel on varied Shaft Speed

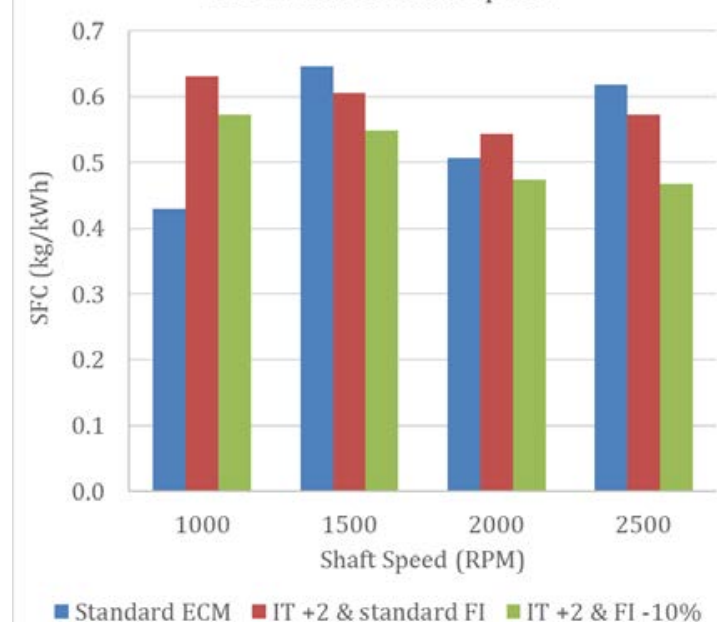

(c)

Fig. 4: SFC with Different RON Fuel on Varied Shaft Speed (a) $88 \mathrm{E} 40$, (b) $92 \mathrm{E} 40$ and (c) $98 \mathrm{E} 0$ - E40 
Likewise, the increase in torque is also higher in the use of fuel with a higher octane value as illustrated in Figure 4, which is 3\% (88 E40), 4\% (92 E40), and 5\% (98 E40) at 2000 RPM shaft speed. Thus, by advancing the ignition timing of $2{ }^{\circ} \mathrm{CA}$ can approach the MBT so the energy released from the combustion process will be efficiently converted to produce optimal power and torque, The higher oxygen content of the fuel to influence a good combustion ${ }^{32)}$.

\section{B. Specific Fuel Consumption}

Figure 3 shows that setting the ignition timing of 2 ${ }^{\circ} \mathrm{CA}$ and reducing the fuel injection duration by $10 \%$, in general, can reduce the SFC, compared to standard ECM conditions with the use of 88 E40, 92 E40, and 98 E40 fuels. The decrease in SFC is greater in the use of fuel with a higher octane value, which is $0.07 \mathrm{~kg} / \mathrm{kWh}(88$ E40), $0.10 \mathrm{~kg} / \mathrm{kWh}$ (92 E40), and $0.15 \mathrm{~kg} / \mathrm{kWh}$ (98 E40) at 2500 RPM shaft speed. This is related to the energy density of 98 E40 fuels which is greater than $92 \mathrm{E} 40$ and $88 \mathrm{E} 40$, the addition of ethanol results in a decrease in calorific value but increases the BSFC ${ }^{31)}$.

\section{Conclusions}

From the studies, it can be concluded that engine performance can be optimized by setting the ignition timing of $2{ }^{\circ} \mathrm{CA}$ and reducing fuel injection duration by $10 \%$. This can increase the engine power compared to standard ECM conditions, both with the use of fuel 88 E40, 92 E40, and 98 E40. The increase in engine power is greater in the use of fuel with a higher octane value, which is 6\% (88 E40), 9\% (92 E40), and 11\% (98 E40) at 2500 RPM shaft speed. Likewise, the increase in torque is also greater in the use of fuel with a higher octane value, which is 3\% (88 E40), 4\% (92 E40), and 5\% (98 E40) at 2000 RPM shaft speed. Furthermore, this setting of ECM can reduce the SFC compared to the standard ECM conditions with the use of fuel 88 E40, 92 $\mathrm{E} 40$, and $98 \mathrm{E} 40$. The decrease in SFC is greater in the use of fuel with a higher octane value, which is 0.07 $\mathrm{kg} / \mathrm{kWh}$ (88 E40), $0.10 \mathrm{~kg} / \mathrm{kWh}$ (92 E40), and 0.15 $\mathrm{kg} / \mathrm{kWh}$ (98 E40) at 2500 RPM shaft speed.

\section{Acknowledgements}

This research was supported by PUTI grant on contract number: NKB-00/UN2.RST/HKP.05.00/2020, Universitas Indonesia.

\section{References}

1) Dijan Supramono, Justin Edgar, "Characteristics of Non-Polar Bio-oil Produced by Co-pyrolysis of Corn Cobs and Polypropylene using CO2 as Carrier Gas, ” EVERGREEN Joint Journal of Novel Carbon Resource Sciences \& Green Asia Strategy. Vol. 06, Issue 01, pp.78-84, March 2019.
2) Ni'mah Ayu Lestari, "Reduction of $\mathrm{CO} 2$ Emission by Integrated Biomass Gasification-Solid Oxide Fuel Cell Combined with Heat Recovery and in-situ CO2 Utilization,” EVERGREEN Joint Journal of Novel Carbon Resource Sciences \& Green Asia Strategy, Vol. 06, Issue 03, pp254-261, September, 2019.

3) Imam Paryanto, Tirto Prakoso, Bambang Heru Susanto, Misri Gozan, "The Effect of Outdoor Temperature Conditions and Monoglyceride Content on the Precipitate Formation of Biodiesel-Petrodiesel Blended Fuel (BXX)," EVERGREEN Joint Journal of Novel Carbon Resource Sciences \& Green Asia Strategy, Vol. 06, Issue 01, pp.59-64, March 2019.

4) Takaya Fujisaki,”Evaluation of Green Paradox: Case Study of Japan,"EVERGREEN Joint Journal of Novel Carbon Resource Sciences \& Green Asia Strategy, Vol. 05, Issue 04, pp.26-31, December 2018

5) Setia Abikusna, Bambang Sugiarto, Iqbal Yamin, "Utilization Analysis of Bioethanol (Low Grade) and Oxygenated Additive to COV and Gas Emissions on SI Engine," EVERGREEN Joint Journal of Novel Carbon Resource Sciences \& Green Asia Strategy, Vol. 07, Issue 01, pp43-50, March, 2020.

6) Tangka J. K., Berinyuy J. E., Tekounegnin and Okale A. N., "Physico-chemical properties of bio-ethanol/gasoline blends and the qualitative effect of different blends on gasoline quality and engine performance," Journal of Petroleum Technology and Alternative Fuels Vol. 2(3), pp. 35-44, March 2011.

7) Fransiskus Adian, Bambang Sugiarto, Cahyo Setyo Wibowo, Ardi Zikra, Try Mulya,"The effect of 5\% ethanol in 88, 92, and 98 RON gasoline on motorcycle engine performance," AIP Conference Proceedings 2114(1):020018 - June 2019.

8) Cahyo Setyo Wibowo, Bambang Sugiarto, Ardi Zikra, Alva Budi, Try Mulya, and May Muchar, "The effect of bioethanol-varying gasoline blends on performance and emission of SI engine 150 cc," (AIP Conference Proceedings 2062, 020020 (2019); https://doi.org/10.1063/1.5086567).

9) H. S. Yucesu, A. Sozen, T. Topgu, E. Arcakliog, "Comparative study of mathematical and experimental analysis of spark ignition engine performance used ethanol-gasoline blend fuel," (Applied Thermal Engineering vol. 27, 2007), pp. 358-368.

10) H. Kim, B. Choi, "Effect of ethanol-diesel blend fuels on emission and particle size distribution in a common-rail direct injection diesel engine with warm-up catalytic converter," (J Renewable Energy, 2008), pp. 2222-2228.

11) Al-Baghdadi, "Measurement and prediction study of the effect of ethanol blending on the performance and pollutants emission of a four-stroke spark 
ignition engine," Mechanical and Energy Engineering Department, Higher Institute of Mechanical Engineering, P.O.Box 65943, Yefren, DOI: 10.1243/09544070JAUTO732, 2008.

12) B. Sugiarto, C. S. Wibowo, A. Zikra, A. Budi, T. Mulya, "The effect of gasoline-bioethanol blends to the value of fuel's octane number (Proceeding, International Tropical Renewable Energy Conference, 2018).

13) Chongming Wang, Soheil Zeraati-Rezaei, Liming Xiang, Hongming $\mathrm{Xu}$, "Ethanol blends in spark ignition engines: RON, octane-added value, cooling effect, compression ratio, and potential engine efficiency gain, Applied Energy 191 (2017) 603-619.

14) H. A. Osman, "Experimental study the effect of octane number on performance of the spark ignition engine," ( $J$ Modern Trends Engineering Research vol.03 issue 06, 2016).

15) C. Wang, S. Rezaei, L. Xiang, H. Xu, "Ethanol blends in spark ignition engines: RON, octane-added value, cooling effect, compression ratio, and potential engine efficiency gain," J Applied Energy vol. 192, 2017), pp. 603-619.

16) Pedro Mello, Fabiano Wildner, Giovanni Souza de Andrade, Renato Cataluna, Rosangela da Silva, "Combustion time of the oxygenated and non-oxygenated fuels in an Otto cycle engine," Springerlink.com, J Braz. Soc. Mech. Sci. Eng. (2014) 36:403-410.

17) Heywood JB. Internal combustion engine fundamentals. McGraw-Hill; 1988.

18) A. Ozcelik, H. Aydogan, M. Acaroglu, "A study of the effects of bioethanol-gasoline blends on vehicle emissions"' (J Clean Energy Technologies vol. 3 no. 5, 2015).

19) William B. Ribbens, "Understanding Automotive Electronics: An Engineering Perspective," 2017 Elsevier Inc.

20) Kar, Kenneth, Wai Cheng, and Kaoru Ishii, "Effects of ethanol content on gasohol PFI engine wide-open-throttle operation," (SAE International Journal of Fuels and Lubricants, 2(1):895-901, 2009).

21) Ritchie Daniel, Guohong Tian, Hongming Xu, Shijin Shuai, "Ignition timing sensitivities of oxygenated biofuels compared to gasoline in a direct-injection SI engine," Fuel 99 (2012) 72-82, http://dx.doi.org/10.1016/j.fuel.2012.01.053.

22) Dale Turner, Hongming $\mathrm{Xu}$, Roger F. Cracknell, Vinod Natarajan, Xiangdong Chen, "Combustion performance of bio-ethanol at various blend ratios in a gasoline direct injection engine," Fuel 90 (2011) 1999-2006, doi:10.1016/j.fuel.2010.12.025.

23) S.A.Iqbal, R.K Sharma, Subrata Bhattacacharjee and M.J Shaikh, "A study of Ethanol Content and Octane Effects in Ethanol Mixed Petrol," Oriental Journal of Physical Sciences, Vol. 2(1), 72-80 (2017).15. Kar and Cheng.

24) G. Martini, U. Manfredi, A. Krasenbrink, "Effect of oxygenates in gasoline on fuel consumption and emissions in three Euro 4 passenger cars," JRC86439, doi: 10.2790/1136.

25) Thomas G. Leone, James E. Anderson, Richard S. Davis, Asim Iqbal, Ronald A. Reese, Michael H. Shelby, and William M. Studzinski, "The Effect of Compression Ratio, Fuel Octane Rating, and Ethanol Content on Spark-Ignition Engine Efficiency," 2015 American Chemical Society, DOI: 10.1021/acs.est.5b01420 Environ. Sci. Technol. 2015, 49, 10778-10789.

26) ASTM D 2699-12 Annual Book of ASTM Standards. (2012). Philadelphia, USA: The American Society for Testing and Materials.

27) ASTM D 4052-11 Annual Book of ASTM Standards. (2012). Philadelphia, USA: The American Society for Testing and Materials.

28) Tibaquirá, J. E., Huertas, J. I., Ospina, S., Quirama, L. F., \& Niño, J. E. (2018). "The Effect of Using Ethanol-Gasoline Blends on the Mechanical", Energy and Environmental Performance of In-Use Vehicles. Energies, 11(1), 1-17. https://doi.org/10.3390/en11010221

29) Petrolia, D. R., Bhattacharjee, S., Hudson, D., \& Herndon, C. W. (2010). "Do Americans want ethanol? A comparative contingent-valuation study of willingness to pay for E-10 and E-85". Energy Economics. https://doi.org/10.1016/j.eneco.2009.08.004

30) Kim, S., \& Dale, B. E. (2006). "Ethanol fuels: E10 or E85 - Life cycle perspectives". International Journal of Life Cycle Assessment. https://doi.org/10.1065/lca2005.02.201

31) Mega Nur Sasongko* and Widya Wijayanti (2017), "Effect of ethanol addition on the performance and exhaust emissions of a spark ignition engine", Journal of Mechanical Engineering and Sciences, ISSN (Print): 2289-4659; e-ISSN: 2231-8380, Volume 11, Issue 2, pp. 2734-2742, June 2017, (C) Universiti Malaysia Pahang, Malaysia, DOI: https://doi.org/10.15282/jmes.11.2.2017.14.0248

32) Luigi De Simio, Michele Gambino, and Sabato Iannaccone, "Effect of Ethanol Content on Thermal Efficiency of a Spark-Ignition Light-Duty Engine", International Scholarly Research Network,ISRN Renewable Energy,Volume 2012, Article ID 219703, 8 pages doi:10.5402/2012/219703 